Marcin Laberschek (D) https://orcid.org/0000-0002-1081-5073

Uniwersytet Jagielloński

marcin.laberschek@uj.edu.pl

Otrzymano/Received: 17.09.2020

Zaakceptowano/Accepted: 15.11.2020

Opublikowano/Published: 11.12.2020

\title{
W cieniu fabryki. Wizja katastrofy Zakladów Azotowych w Mościcach w pomniku Wilhelma Sasnala
}

\section{Abstract \\ In the Shadow of the Factory. A Vision of the Nitrogen Plant Disaster in Mościce at the Monument of Wilhelm Sasnal}

The article concerns the shadow phenomenon understood as the state of anxiety of people who create the social environment of an organization. This phenomenon was discussed on the example of Zakłady Azotowe in Mościce and the Wilhelm Sasnal monument, using research material from indepth interviews with the creator of the monument and with Dawid Radziszewski, artistic curator. Information from existing sources and the results of the visual analysis of the monument were also used. The result of the analysis is that: (1) shadow is a kind of social fear of threats from the organization (e.g., failures); (2) its source is the organization itself; (3) shadow is rooted in the past (4) and projected for the future; (5) shadow organizes social life in the environment of the organization and manifests itself in stories, myths and art.

Keywords: organizational shadow, monuments of the organization, art and management, collective representations

Słowa kluczowe: cień organizacyjny, pomniki organizacji, sztuka i zarządzanie, wyobrażenia zbiorowe 


\section{Cien jako zbiorowe wyobrażenie lęku}

Określenie „w cieniu wulkanu” występuje w analogicznej postaci w wielu językach, we francuskim: à lombre du volcan, angielskim: in the shadow on a volcano, we włoskim: all’mbra del vulcano, w niemieckim: Im Schatten des Vulkans czy choćby w węgierskim: a vulkán árnyékában, i oznacza dokładnie to samo. To tym bardziej ciekawe, że jest to określenie metaforyczne. W każdym przypadku chodzi o swego rodzaju siłę o negatywnym zabarwieniu, mającą swoje źródło w wulkanie, a oddziałującą na jego otoczenie, również społeczne. W społecznym znaczeniu tak rozumiany cień jest więc pewnym stanem zagrożenia, odczuciem lęku towarzyszącym tym osobom, które pozostają w relacji z czynnym wulkanem. Można tutaj podać przykład położonego nad Zatoką Neapolitańską Wezuwiusza. Ten aktywny wulkan budzi strach wśród lokalnej społeczności, ponieważ w każdym momencie może dojść do podobnej erupcji, jaka miała miejsce w 79 roku, kiedy warstwa materiału piroklastycznego i pumeksu zniszczyła miasta Herkulanum, Stabie i Pompeje.

Tego rodzaju cień ma niebagatelne znaczenie, gdyż porządkuje życie ludzi, którzy poddani są jego wpływowi, zarówno w życiu codziennym, jak i w sferze wyobraźni. Wulkan i wszystko, co z nim związane, staje się symbolicznym motywem tradycyjnych i współczesnych rytuałów, opowieści, mitów, a także pieśni, tańca, sztuki i wielu innych aspektów ludzkiej aktywności. Przykłady pochodzą z całego świata. Według greckiej mitologii z włoskim wulkanem Etna związana jest postać Hefajstosa, boga kowali, złotników i ognia. To właśnie we wnętrzu Etny znajdowała się kuźnia Hefajstosa. Wydobywający się z krateru dym był dla okolicznych mieszkańców znakiem, że boski kowal rozpoczął swą pracę. Z kolei na Hawajach znajduje się wulkan Kilaueua, który zgodnie z lokalną tradycją zamieszkuje bogini Pele. Erupcje wulkanu są przejawami gniewu Pele. Przypisywanie boskiego znaczenia wulkanom nie było przypadkowe, najprawdopodobniej wiązało się z respektem, z jakim do wulkanów podchodziły społeczności zamieszkujące $w$ ich pobliżu. Nierzadko więc $w$ różnych częściach świata odbywały się rytuały składania wulkanicznym bogom darów i ofiar. Działo się tak choćby na terenie dzisiejszego Peru, gdzie Inkowie składali bogom ofiary w postaci dzieci, które umieszczano w kraterze wulkanu Misti. Natomiast w Indonezji do dzisiaj odbywa się ceremonia Kasada polegająca na oddaniu czci bogom poprzez wrzucanie do krateru wulkanu Bromo żywności i kwiatów.

Wszystkie przytoczone przykłady świadczą o sile oddziaływania wulkanów na ludzi. To ta właśnie siła jest cieniem. Jednakże nie o cieniu wulkanu traktuje niniejszy artykuł, a o cieniu fabryki. Metafora wulkanu ma przede wszystkim dać czytelnikowi właściwe wyobrażenie tego, o jaki rodzaj cienia chodzi w odniesieniu do siły, z którą zmagali się w przeszłości i wciąż zmagają mieszkańcy tarnowskiej dzielnicy Mościce, poddawani permanentnemu oddziaływaniu tamtejszych Zakładów Azotowych. Paralela ta ma także dać wyobrażenie, w jaki sposób cień fabryki organizuje społeczne życie jej otoczenia. 
Zastanawiające jest, że to, wydawałoby się dość powszechne, ujęcie cienia nie ma swojej reprezentacji w Słowniku języka polskiego PWN (Drabik i in. 2007). Pośród sześciu zawartych tam definicji (Drabik i in. 2007, s. 100) nie ma takiej, która odpowiadałaby nakreślonemu tutaj znaczeniu. Inaczej wygląda sytuacja w Słowniku symboli Władysława Kopalińskiego (2001). Z wielu podanych w nim propozycji rozumienia tego terminu na jedną trzeba zwrócić uwagę: chodzi o cień odnoszący się do sytuacji ludzi „żyjących w cieniu” (Kopaliński 2001, s. 43). W celu zobrazowania tego znaczenia Kopaliński przywołuje powieść Emila Rosenowa z 1899 roku Die im Schatten Leben (Żyjący w cieniu), będącą studium robotniczego ubóstwa, opowieścią o życiu górniczej rodziny, której codzienność jest całkowicie zdeterminowana przez położoną pod Dortmundem kopalnię, choćby przez panujące w niej warunki pracy i industrialną, niepokojącą atmosferę. W tym miejscu warto podkreślić podobieństwo owej sytuacji do cienia wulkanicznego. Kopalnia jak wulkan jest źródłem cienia (lęku), który w jednym i drugim przypadku organizuje życie ludzi znajdujących się w otoczeniu tego źródła. Mając oczywiście na uwadze fikcyjność sytuacji przedstawionej przez Rosenowa, należy stwierdzić, że jest ona jednak analogiczna do omawianego w artykule przypadku Zakładów Azotowych. W jednym i drugim przypadku chodzi bowiem o cień wywoływany czy wręcz rzucany przez przedsiębiorstwo.

Wypada teraz zadać pytanie o status ontologiczny tak rozumianego cienia. Owszem, pojawiły się już takie określenia, jak: „siła o negatywnym zabarwieniu”, „stan zagrożenia”, „odczucie lęku”, jednak póki co trudno jednoznacznie ująć, jaka jest istota, natura cienia, a mówiąc wprost, czym on właściwie jest. Przydatna będzie tutaj kategoria „zbiorowego wyobrażenia” wprowadzona przez Émile’a Durkheima. Otóż Durkheim twierdził, że to charakterystyczny i wspólny dla przedstawicieli danej grupy społecznej sposób myślenia. Uważał też, że „życie społeczne składa się w całości z wyobrażeń" (Durkheim 1901/2000, s. 5), które odnoszą się do sposobu, „W jaki społeczeństwo, ów byt specyficzny, przetwarza myślowo to, co należy do jego własnego doświadczenia" (Durkheim 1912/2010, s. 373). Wyobrażenia zbiorowe są więc swego rodzaju ramami odniesienia nakładanymi przez społeczeństwo na rzeczywistość, które w pewnym sensie zakrzywiają tę rzeczywistość. Omawiany tutaj cień należy traktować jako szczególną kategorię wyobrażenia zbiorowego, szczególną, bo, jak wspomniano, o negatywnym zabarwieniu. Warto przy tym podkreślić, że postać cienia nie jest formowana li tylko w przestrzeni społecznej, w relacjach międzyosobowych. Żadna bowiem społeczność nie jest odizolowana od warunków środowiska fizyczno-przyrodniczego; nie można przecież pominąć wpływu obiektów (choćby wspomnianych wulkanów lub fabryk) i zjawisk natury fizycznej (np. dźwięków, warunków atmosferycznych) na kształtowanie się cienia, jak i szerzej, wyobrażeń zbiorowych. Należy więc podkreślić, że cień będący wyobrażeniem zbiorowym mieszkańców Mościc był i jest formowany w ramach interakcji społecznych, ale też na styku społeczności i materialnie pojmowanej fabryki. Tych 
dwóch perspektyw nie można traktować rozdzielnie. Poza tym cień ten, rozumiany jako zbiorowe wyobrażenie niepokoju, lęku, w taki właśnie „lękowy” sposób wpływał i wpływa na postrzeganie oraz interpretację rzeczywistości, jakiej doświadczają mieszkańcy Mościc. Przejawia się to w powstawaniu szczególnego rodzaju domysłów, tajemnic, opowieści, mitów, ale też w symptomatycznej twórczości Wilhelma Sasnala - mościczanina i jednego z najbardziej rozpoznawalnych polskich artystów sztuk wizualnych. Te wszystkie elementy zostaną zgłębione w kolejnych odsłonach pracy.

\section{Lokalizacja cienia}

Niniejszą pracę napisano w optyce nauk o organizacji i zarządzaniu. Wynika to z dwóch powodów. Pierwszym są zainteresowania naukowe autora, drugim - przedmiot badań. Jak sygnalizowano, opracowanie to poświęcono cieniowi rzucanemu przez Zakłady Azotowe w Mościcach na otoczenie społeczne, który to cień, jako szczególnego rodzaju zbiorowe wyobrażenie, wpływa na zachowania tego otoczenia. Zakłady Azotowe to przedsiębiorstwo, czyli organizacja gospodarcza, a to właśnie problematyką organizacji zajmują się nauki o zarządzaniu. Co prawda interesujące zjawisko cienia nie dotyczy samej organizacji, a środowiska, w którym działa, wiele jednak badań z zakresu zarządzania nakierowanych jest właśnie na jej otoczenie. Mowa choćby o analizie mikro- i makrootoczenia prowadzonej w celu określenia potencjalnych szans i zagrożeń dla organizacji (Gierszewska, Romanowska 2003) czy też o wszelkiego rodzaju badaniach marketingowych, w których ostatecznie chodzi o to, by „zdobyć przewagę rynkową" (Maison 2010, s. 11). Różnica jest jednak taka, że podejścia te mają naturę postekonomiczną, a ich dążeniem jest poprawienie kondycji organizacji, zwiększenie jej efektywności przy wykorzystaniu obiektywnych danych. Tymczasem cień, którego przejawów również należy poszukiwać w otoczeniu, jest kategorią niematerialną. Otoczenie organizacji to bowiem nie tylko konkretne miejsce, ludzie i mierzalne zjawiska, ale także sfera wyobrażeń, którą spowita jest organizacja. Nie jest to zatem klasyczna i modernistyczna perspektywa pojmowania organizacji i jej otoczenia, ale interpretatywno-symboliczna (Hatch 2002; Sułkowski 2007), w przypadku której interesujące są znaczenia tego, co ludzie robią, a nie modelowe, mierzalne zasady. To właśnie w tej niematerialnej sferze znaczeń i wyobrażeń zakorzeniony jest cień organizacyjny. Dlatego też jego eksploracja wymaga zupełnie innego podejścia: badań humanistycznych z zakresu antropologii i estetyki. Badania tego typu nie mają wymiaru aplikacyjnego, a poznawczy - w przypadku cienia chodzi o pozyskanie wiedzy z zakresu permanentnego i przenikliwego oddziaływania organizacji na ludzką wyobraźnię, odciskanego przez nią piętna. Oczywiście wiedza ta może mieć wartość pragmatyczną dla samej organizacji, może przecież być katalizatorem zmian w strategii jej rozwoju, jednakże kwestia ta nie będzie tutaj zgłębiona. 
W naukach o zarządzaniu istnieje wiele perspektyw, gdy chodzi o problematykę cienia. Najbardziej rozpowszechnioną jest koncepcja cienia organizacyjnego zaadaptowana z psychoanalizy, oparta na idei jungowskiego archetypu cienia (Bowles 1991; Carr 2002). Podobnie jak w przypadku człowieka, tego rodzaju cień jest wstydliwym i ukrywanym (tłumionym) obszarem funkcjonowania organizacji (Kostera 2010), który jest przesłonięty innym, przeciwnym, pozytywnym obliczem organizacji, choćby odpowiednio wykreowanym wizerunkiem. Bywa jednak, że cień wychodzi z ukrycia i najczęściej dzieje się to w sposób niekontrolowany przez organizację (Bowles 1991). Są też dwa odmienne podejścia do cienia w organizacji, oba odnoszą się do koncepcji „zarządzania w cieniu” (shadow management). Pierwsze dotyczy sytuacji, gdy organizacja nie jest zarządzana przez osoby piastujące kierownicze stanowiska, a de facto przez niefunkcyjnych członków organizacji. Mechanizm ten jest ukryty i odbywa się niejako w tle tego, co oficjalne (Burduş 2011). Drugie podejście również związane jest z praktyką zarządzania: z takimi działaniami menadżerów, które pozostają w niezgodzie z przepisami prawa i regulaminami, mając przy tym charakter niejawny, zakulisowy (Sörensen, Olsson 2020).

Warto zauważyć, że wszystkie powyższe ujęcia cienia odnoszą się do wewnętrznych aspektów życia organizacji, dotyczą jej samej. Brakuje natomiast takich, które lokowałyby to zjawisko poza organizacją, w jej otoczeniu, a którego źródłem jest organizacja. Tutaj natomiast przyjęto taką właśnie optykę. Zanim zostanie podjęta próba omówienia tak rozumianego cienia na podstawie, jak już kilkukrotnie zaznaczono, konkretnego przypadku Zakładów Azotowych w Mościcach, należy niektóre kwestie wyjaśnić. Podział na cień zlokalizowany wewnątrz organizacji i poza nią może wydawać się wątpliwy. Ta wątpliwość może wynikać z przyjętego w pracy paradygmatu interpretatywno-symbolicznego, u podstaw którego leży koncepcja konstruktywizmu społecznego (Burrell, Morgan 1979). Zgodnie z tą perspektywą poznawczą rzeczywistość nie ma obiektywnego charakteru, a intersubiektywny, to znaczy, że wszelka wiedza człowieka jest tworzona, negocjowana w relacjach między ludźmi i jako swego rodzaju konstrukt zapamiętywana jest przez każdego człowieka. Te wewnętrzne (subiektywne) konstrukty służą ludziom do interpretacji rzeczywistości, której doświadczają. Cień, tutaj potraktowany jak „wyobrażenie zbiorowe lęku", jest również takim konstruktem. Powstaje choćby poprzez wzajemne przekazywanie sobie opowieści o zagrożeniach, konstruowany jest w sieciach relacji stworzonych przez ludzi i obiekty materialne, które budzą lęk (np. wulkany czy fabryki). $Z$ tego punktu widzenia być może trudno wyobrazić sobie to, by cień mógł być zlokalizowany „poza” organizacją, gdzieś „na zewnątrz”, skoro zgodnie z ontologią konstruktywistyczną zarówno cień, jak i organizacja są bytami subiektywnymi, oba należą więc do „świata wewnętrznego” ludzi. Żeby być „poza” organizacją, cień musiałby przestać być wyobrażeniem (konstruktem), musiałby zmaterializować się, co wydaje się dość dziwne. Trzeba jednak podkreślić, że w niniejszym opracowaniu nie chodzi o fizyczne umieszczenie cienia poza człowiekiem ani, bynajmniej, o jego 
materializowanie, chodzi natomiast o umieszczenie go w subiektywnym konstrukcie, który nosi nazwę „otoczenia organizacji”, a nie w konstrukcie „organizacji”. Przyjmując takie założenie, można więc powiedzieć, że cień znajduje się poza organizacją, gdyż otoczenie organizacji jest subiektywnym tworem tego, co znajduje się poza nią. Jest to swego rodzaju figura teoretyczna i taki właśnie punkt widzenia przyjmuje autor niniejszego opracowania.

Nie jest zresztą to nic nowatorskiego. Badacze tworzą teoretyczne ujęcia organizacji, oddzielając ją od otoczenia, w którym działa. Robi się to na różne sposoby, wystarczy jednak dokonać prostej operacji podziału ludzi, którzy odgrywają określone role: ci, których nazywa się pracownikami, tworzą przecież organizację, natomiast klienci jej otoczenie. Oczywiście w niniejszej pracy przyjmuje się, że otoczenia nie tworzą klienci, a mieszkańcy Mościc i jednocześnie sąsiedzi Zakładów Azotowych. Przy okazji warto podkreślić, że nie tylko badacze tworzą tego rodzaju konstrukty teoretyczne. Również same organizacje to robią, i również może to dotyczyć ich własnego otoczenia; takie konstrukty powstają, gdy na przykład tworzą segmentację swoich klientów, kreślą i realizują plany współpracy z dostawcami czy opracowują kanały dystrybucji. To rodzaj tworzenia sensu (Weick 2016) lub porządkowania rzeczywistości (Garfinkel 2007) - w tym przypadku środowiska, w którym organizacja działa. Podsumowując powyższe: autor opracowania stworzył teoretyczną figurę otoczenia organizacji (złożoną z rzeczywistych mieszkańców Mościc), w obrębie którego (a nie samej organizacji) podjął się eksploracji i zrozumienia zjawiska cienia.

Przyjętą tutaj koncepcję cienia, który istnieje poza organizacją, a nie „wewnątrz”, można dodatkowo uzasadnić w inny sposób. Warto zwrócić uwagę, że przeniesienie jungowskiej koncepcji cienia na grunt nauk o zarządzaniu i organizacji stało się możliwe dzięki potraktowaniu organizacji jak osoby. Tak pojmowaną organizację nazywa się często „superosobą” (Kostera 2010; Kostera, Śliwa 2012). Analogicznie więc jak w przypadku ludzi, cień organizacji (superosoby) jest jej ciemną, wstydliwą stroną, która jest skrywana przed otoczeniem i spychana do jej nieświadomości. Owszem, od czasu do czasu dochodzi do niekontrolowanego ujawniania się cienia i wówczas negatywne cechy organizacji wychodzą na jaw. Do tych negatywnych cech nie ma jednak dostępu, ponieważ, dokładnie jak w przypadku konkretnego człowieka, są one elementem wewnętrznego świata superosoby. Pozostają zamknięte dla osób z zewnątrz. Można jedynie doświadczać negatywnych skutków cienia, i to zazwyczaj w niespodziewanych momentach i sytuacjach. Warto zwrócić uwagę, że figura superosoby pozwala dokonać podziału na świat wewnętrzny i zewnętrzny. Ten pierwszy jest wnętrzem superosoby, można powiedzieć - jej osobowością (gdzie odkłada się jungowski cień), ten drugi jest natomiast jej otoczeniem, przestrzenią, w której działa, ludźmi, którymi się otacza. To rozróżnienie jest ważne, gdyż przedmiotem niniejszej pracy nie jest cień superosoby, a cień osób z jej otoczenia, osób, z którymi wchodzi w relacje. Nie chodzi tutaj zatem o cień organizacji, a o cień środowiska społecznego, w którym organizacja funkcjonuje. Co więcej, o cień wywołany 
przez negatywne działanie tej organizacji. Zaprezentowany w tej pracy przykład Zakładów Azotowych w Mościcach i okolicznych mieszkańców jest ilustracją tego teoretycznego ujęcia cienia.

\section{Pomnik Wilhelma Sasnala i cién Zakladów Azotowych w Mościcach}

Autor niniejszej pracy od maja 2018 roku prowadzi badania dotyczące pomników związanych ze szczególnego rodzaju organizacjami, jakimi są przedsiębiorstwa. W tym czasie stworzył bazę ponad 300 znajdujących się na terenie Polski takich właśnie obiektów. Istnieją pomniki, które stawiane są z inicjatywy samych przedsiębiorstw, i wówczas zazwyczaj pełnią one określoną funkcję, na przykład tożsamościową (choćby pomniki ojców założycieli, symboli organizacji), pamiątkową (monumenty starych maszyn), estetyczną (pomniki abstrakcyjne) czy też reklamową i wizerunkową (Laberschek 2019a; Laberschek 2019b; Laberschek 2021). Z drugiej strony są też pomniki, których inicjatywę stworzenia podejmują osoby bądź grupy osób $z$ otoczenia organizacji. Tych monumentów nie należy postrzegać jako "narzędzia”, dzięki którym organizacje mogą, często w sposób symboliczny, realizować swoje cele. Jest to natomiast fizyczny ślad oddziaływania organizacji na otoczenie, jej wpływu na nie. „Czytając” pomnik, można dojść do wniosku, jaki rodzaj oddziaływania miał miejsce. Samo zresztą postawienie pomnika jest informacją, że potencjał tej siły jest względnie istotny. Pomników nie stawia się bowiem przypadkowo.

Jednym z obiektów należącym do tej drugiej kategorii jest zlokalizowany w Mościcach (dzielnicy Tarnowa) pomnik autorstwa wspomnianego wcześniej artysty, Wilhelma Sasnala, który, mieszkając w pobliżu Zakładów Azotowych, dojrzewał w specyficznym fabrycznym mikroklimacie. Pomnik stworzony z 14 betonowych rur kanalizacyjnych, pokrytych smołą i ustawionych w formie piramidy, odsłonięto 29 sierpnia 2010 roku nieopodal dworca kolejowego Tarnów-Mościce. Wydarzenie to i sam obiekt (widoczne na fotografii 1) były częścią większego projektu, organizowanej przez Biuro Wystaw Artystycznych w Tarnowie wystawy Tarnów. 1000 lat nowoczesności, której kuratorem był Dawid Radziszewski. Akcent tego przedsięwzięcia został położony na modernistyczną historię Tarnowa, a zwłaszcza Mościc.

Wspomniano o stworzonym przez autora tego opracowania katalogu (bazie) pomników polskich przedsiębiorstw. By można było zakwalifikować konkretny obiekt do bazy, musiał przejść odpowiednią procedurę potwierdzającą jego związek z określonym przedsiębiorstwem. Brano pod tutaj uwagę trzy elementy: formę pomnika (zwłaszcza to, co przedstawiał), jego usytuowanie (które nie zawsze miało jednak znaczenie) oraz informacje na jego temat. Decydujące znaczenie miał najczęściej ten ostatni aspekt, ale nie tylko w odniesieniu do tego, czy związek występuje, ale zwłaszcza, jaki ten związek jest, to znaczy, do jakich okoliczności się odwołuje, co go tworzy. Podobną procedurę poszukiwania związku z Zakładami Azotowymi 


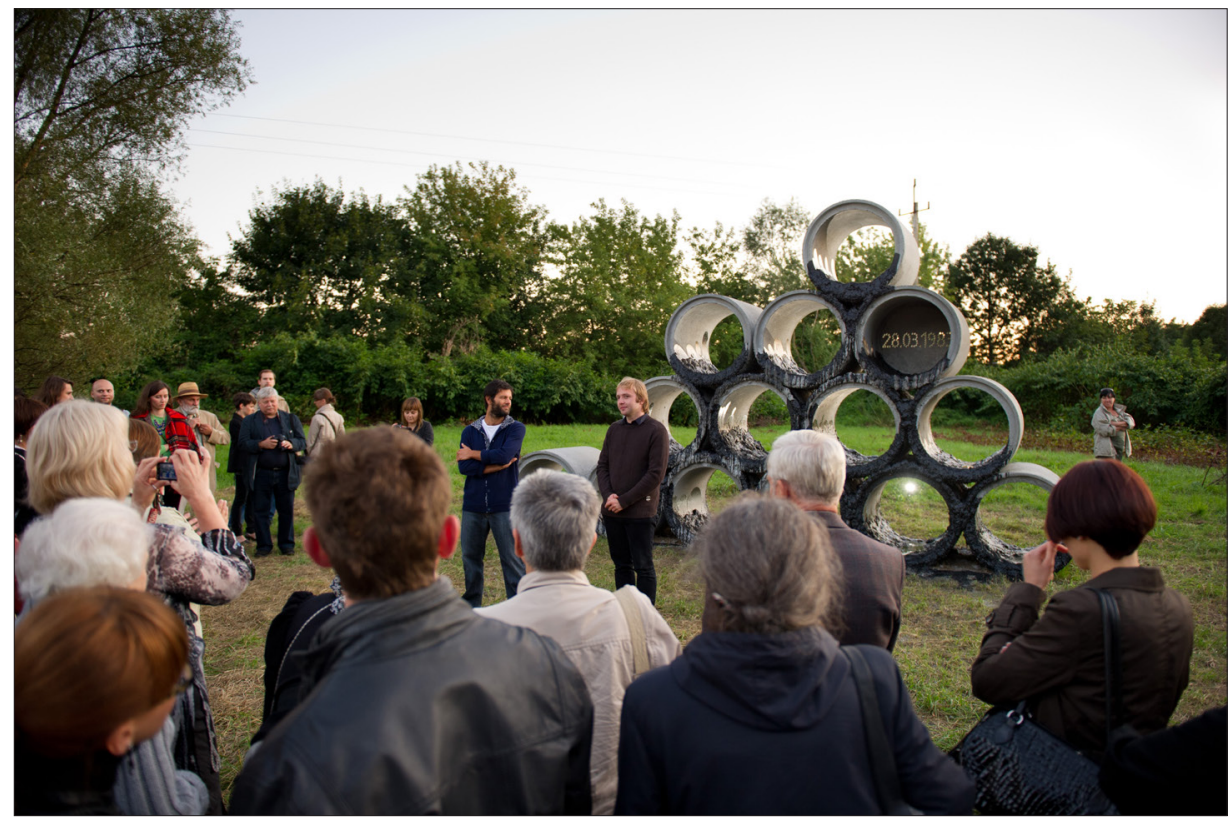

Fotografia 1. Odsłonięcie pomnika Wilhelma Sasnala w Mościcach, 29.08.2010 Autor: Paweł Topolski.

Źródło: BWA Tarnów.

w Mościcach przeszedł pomnik Wilhelma Sasnala. Potwierdzenie tej relacji nie było skomplikowaną operacją. Natomiast informacja o tym, co łączy monument z przedsiębiorstwem, stała się punktem wyjścia do napisania niniejszego opracowania. Tę informację autor odnalazł w artykule Piotra Polichta Artystyczny przewodnik po Tarnowie w serwisie Culture.pl. Otóż według Polichta związek ten dotyczy cienia, a właściwie, jak się wyraził, „podwójnego cienia”, który „Zakłady Azotowe rzucały na Mościce" (Policht 2020). Co ciekawe, nie było to jedyne źródło, w którym pojawiło się określenie „cienia” w kontekście Zakładów Azotowych; odnaleziono je także w tytule artykułu Arcydzieło w cieniu zakładów azotowych (Arcydzieło 2008), który powstał jeszcze przed wzniesieniem pomnika, a także w słowach Dawida Radziszewskiego pochodzących z wywiadu przeprowadzonego na potrzeby tego tekstu. Radziszewski uważał, że mościczanie „żyli w cieniu” fabryki (Radziszewski 2020). Trzeba podkreślić, że tego rodzaju pojęcie cienia nie jest syntetyczną, wytworzoną przez badacza kategorią naukową, czyli, jak powiedziałby Bruno Latour, pojęciem ostensywnym (Latour 1986), ale powstałym naturalnie, „oddolnie” - określeniem performatywnym (Latour 1986). Ta „naturalność” i różne źródła identyfikacji cienia są dodatkowym argumentem za dopuszczeniem perspektywy o istnieniu w otoczeniu Zakładów Azotowych pewnej siły i zmuszają do zadania pytania o istotę tej siły. 


\section{Spoleczny i estetyczny wymiar badań nad cieniem Zakladów Azotowych}

W kontekście tak rozumianego cienia fabryki zrodziło się pytanie badawcze: czym ten cień jest i na czym polega przejawiająca się w dziele Wilhelma Sasnala i wskazana przez Piotra Polichta jego „podwójność”? Ale też: w jaki sposób cień powstaje i co go utrzymuje w obiegu społecznym, jak wpływa na otoczenie Zakładów Azotowych, jak kształtuje wyobraźnię mieszkańców Mościc?

Pierwszy trop w kierunku uzyskania odpowiedzi na powyższe pytania zawarty był w słowach Polichta, który we wspomnianym artykule przybliżył koncepcję cienia i odniósł się do społecznego kontekstu powstania monumentu:

Dorastający w latach 80. artysta w prostej formie zawarł esencję zimnowojennego strachu, który w przedwojennej przemysłowej dzielnicy krystalizował się niezwykle intensywnie. Zakłady Azotowe rzucały na Mościce podwójny cień - z jednej strony czyhała obawa przed katastrofą na modłę czarnobylską, z drugiej wyobrażenie amerykańskich rakiet, wycelowanych rzekomo w fabrykę jako jeden z celów strategicznych (Policht 2020).

Według Piotra Polichta wyrażony w dziele Sasnala cień jest rodzajem stanu lękowego („strachem”, „obawą)) przed katastrofą, jaka mogła stać się udziałem Zakładów Azotowych w okresie Polski Ludowej. Wyraźnie rysuje się tutaj analogia z omawianą wcześniej koncepcją cienia wulkanu, czyli życia w permanentnym lęku przed kataklizmem. Z drugiej strony Policht, odnosząc się do rzekomego ataku rakietowego, używa pojęcia „wyobrażenia”. Nie chodzi tutaj jednak o wyobrażenie jednostkowe, a dotyczące „przemysłowej dzielnicy”, którą należy oczywiście rozumieć w sensie społecznym. To właśnie ten punkt widzenia pozwolił autorowi pracy wysnuć przypuszczenie, że może chodzić tutaj o rodzaj durkheimowskiego „wyobrażenia zbiorowego", ale pod szczególną jego postacią, postrzeganą jako społeczny stan zagrożenia, czyli cień. To właśnie na fundamencie koncepcji Durkheima zaprojektowano odpowiednie badania, których celem było zgłębienie istoty tak rozumianego cienia mościckiej fabryki.

W badaniach nad cieniem, w poszukiwaniach wątków bezpośrednio i pośrednio z nim związanych, wykorzystano trzy metody: wywiadu pogłębionego, analizy źródeł zastanych oraz analizy wizualnej. Przeprowadzono dwa wywiady: $w$ formie bezpośredniego spotkania $\mathrm{z}$ autorem pomnika, Wilhelmem Sasnalem, oraz telefoniczny (dodatkowy, uzupełniający) z kuratorem wspomnianej wcześniej wystawy Tarnów. 1000 lat nowoczesności, Dawidem Radziszewskim. Oba wywiady przybrały formę swobodnej, choć w zakresie problemu badawczego, kierowanej rozmowy (Czarniawska 2002; Kostera 2003). Sposób prowadzenia wywiadów oparty był na perspektywie emocjonalizmu, która „[p] ]omaga zrozumieć doświadczenia ludzi, ale za cenę uprzywilejowania kategorii potocznych (»emocji«)" (Silverman 2012, s. 66). 
Durkheim opowiadał się za badaniem obiektywnie istniejących i tworzonych pomiędzy pokoleniami faktów społecznych, dlatego też był przeciwnikiem eksploracji indywidualnej perspektywy ludzi. To, co indywidualne, nie było według niego tym samym, co zbiorowe. Jednakże prowadzony z Sasnalem wywiad o charakterze biograficzno-narracyjnym (Biały 2015) był nakierowany przede wszystkim na pozyskanie takich wspomnień, w których aspekt społeczny miał szczególne znaczenie. Wspomnień, które wynikały z jego relacji z innymi mieszkańcami Mościc, kolegami i rodziną, zarówno w sensie horyzontalnym (w obrębie tego samego pokolenia), jak i wertykalnym (międzypokoleniowo). Z jednej więc strony artysta twierdził, że wiedza, którą posiada, miała powszechny charakter i propagowana była przez rówieśników - pochodziła „od kolegów” (Sasnal 2020), z drugiej powoływał się na opowieści, których źródłem były jego babcia i mama (Sasnal 2020). Wszystkie te opowieści formowały zatem zbiorową świadomość, a nie tylko świadomość samego Sasnala.

Podczas wywiadów z rozmówcami koncentrowano się przede wszystkim na tym, by pozyskać historie, unikano natomiast dokonywania przez rozmówców ocen i uogólniania. Jest to zgodne z postulatami badaczy o nastawieniu antropologicznym (Czarniawska 2002; Kostera 2003). Zwracano uwagę na historie odnoszące się nie tylko do relacji pomiędzy ludźmi, istotne były też wspomnienia dotyczące interakcji ludzi z fabryką, jej fizycznego oddziaływania na otoczenie. Ważne były też opowieści o pomniku Wilhelma Sasnala.

Pozyskany $\mathrm{z}$ wywiadów materiał badawczy poddano interpretacji. W jej ramach identyfikowano i poddawano analizie wątki o charakterze antropologicznym i estetycznym. Stały się one punktem wyjścia do napisania empirycznej części pracy. Poszukiwane w materiale kategorie antropologiczne dotyczyły wskazanych przez Monikę Kosterę symboli, rytuałów, ceremonii, mitów i instytucji (Kostera 2003). Symbole to „te przedmioty, które nabierają znaczenia” i są „cząsteczkami kodu kultury" (Kostera 2003, s. 168). W materiale wyszukano wiele symboli. Pojawily się choćby: symboliczne „szczekaczki” (megafony uliczne), symbolem jest sam pomnik i umieszczona na nim data „28.03.1983” oraz syrena jako symboliczny sygnał. Choć nie zidentyfikowano rytuałów i ceremonii, to niektóre zachowania mościczan można uznać za instytucje, czyli zmechanizowane i utrwalone praktyki ludzkie. Był to na przykład zmianowy system pracy wyznaczany przez wspomnianą syrenę. Wiele natomiast pojawiło się mitycznych opowieści, by wspomnieć te o katastrofie zakładów, które stanowią fundament niniejszej pracy.

W materiale badawczym poszukiwano też wątków estetycznych. Chodziło o działania artystyczne Wilhelma Sasnala, na które wpływ miały Zakłady Azotowe. Mowa tutaj nie tylko o pomniku, ale także o projekcie polegającym na puszczaniu muzyki przez szczekaczki.

W ramach badań zebrano i przeanalizowano również źródła zastane, zwłaszcza artykuły zamieszczone $\mathrm{w}$ internecie. Nie stosowano doboru ilościowego, a celowy - problem badawczy wyznaczał przydatność tekstów. Zebrano więc artykuły 




Fotografia 2. Pomnik Wilhelma Sasnala w Mościcach, lipiec 2020 r.

Źródło: archiwum autora.

o pomniku Wilhelma Sasnala i innych jego dziełach inspirowanych Zakładami Azotowymi, jak również teksty o samym przedsiębiorstwie, zwłaszcza w kontekście jego wpływu na otoczenie społeczne, w tym na temat rzekomych i rzeczywistych awarii. Cennym źródłem wiedzy była też książka Tarnów. 1000 lat nowoczesności. Przewodnik (Łączyńska-Widz, Radziszewski 2010). W źródłach zastanych również poszukiwano antropologicznych (kulturowych) i estetycznych wątków.

Dodatkową metodą wykorzystaną w opracowaniu była analiza wizualna, której wdrożenie wymaga od badacza potraktowania pomnika jako nośnika znaczeń (Mytych 2018). W przypadku mościckiego pomnika nie było to jednak takie proste, ponieważ nie ma on figuratywnej formy, a metaforyczną (co widać na fotografii 2). $\mathrm{Z}$ tego powodu obiekt bywa również nazywany rzeźbą, instalacją lub konstrukcją. Można jednak zidentyfikować symboliczne elementy, które wiążą postać monumentu z cieniem Zakładów Azotowych. Tego typu analiza przypomina antropologiczne interpretacje pieśni, opowieści czy malowideł powstałych wśród społeczności zamieszkujących wulkaniczne tereny, w których to dziełach w sposób symboliczny ukazana jest relacja człowiek-niebezpieczna natura. Dzieła te uzasadniają i wyznaczają granice tego stosunku. Podobnie można traktować dzieło Sasnala. W antropologii do interpretacji elementów symbolicznych i poszukiwania znaczeń wykorzystuje się często „opis gęsty” (Geertz 2005). Clifford Geertz twierdził, że aby dokonać odpowiedniej 
interpretacji tego, co interesuje badacza, trzeba pamiętać również o kontekście. Bez uwzględnienia kontekstu interpretacja może okazać się błędna. Analizę wizualną pomnika połączono więc z perspektywą „opisu gęstego”. Do właściwego zrozumienia tego, czym jest dzieło (pomnik) i co oznaczają jego poszczególne elementy, wzięto pod uwagę kontekst $\mathrm{w}$ postaci informacji pozyskanych $\mathrm{z}$ wywiadów $\mathrm{z}$ Sasnalem i Radziszewskim oraz ze zgromadzonych materiałów zastanych.

\section{Podwojiny cien Zakladów Azotowych}

Środowisko społeczne mościczan jest na swój sposób wyjątkowe - przede wszystkim ze względu na nierozerwalne połączenie $\mathrm{z}$ istniejącymi na tym terenie Zakładami Azotowymi, które są fundamentalną częścią jego tożsamości. Przedsiębiorstwo branży chemicznej powstało w 1930 roku na terenie kilku wsi położonych pod Tarnowem. Miejsce, w którym zlokalizowano fabrykę wraz z otaczającą ją aglomeracją mieszkalną, nazwano Mościcami; był to symboliczny gest w stronę ojca założyciela zakładów - Ignacego Mościckiego. Co ciekawe, a co świadczy o sile tożsamościowej nazwy Mościce, kiedy w czasach Peerelu zmieniono ją na Świerczków (tak nazywała się jedna z wsi, na której terenie zlokalizowano zakłady), niektórzy mieszkańcy nie odebrali entuzjastycznie tego pomysłu. Jak wspomina Sasnal: „Moją babcię bardzo denerwowała nazwa Świerczków, nigdy jej nie używała. Ja [też - przyp. autora] czuję się mościczaninem" (Czuję 2010, s. 194). Co prawda słowa twórcy nie odnoszą się do społecznej perspektywy, wydaje się jednak, że postawy babci, jak i jego samego nie powinno się postrzegać jako odosobnionych.

Od początku przedsiębiorstwo miało strategiczne znaczenie dla polskiej gospodarki. Już w czasach Polski Ludowej pracowało w nim kilkanaście tysięcy osób, obecnie natomiast (2020 rok) wraz z innymi zakładami wchodzi w skład Grupy Azoty S.A., największego w Polsce koncernu chemicznego. Tak duże przedsięwzięcie nie pozostawało więc bez wpływu na lokalne otoczenie. Fabryka organizowała życie społeczne, zarówno w sensie pragmatycznym, nadając rytm życiu mościczan, jak i kształtując sferę ich wyobrażeń, na co wpływ miała przede wszystkim niebezpieczna działalność chemiczna. To ona kładzie się cieniem na mieszkańcach Mościc, a cień, jako wewnętrzny niepokój przyjmujący różne postaci, staje się z kolei swego rodzaju podglebiem powstawania rozmaitych domysłów, opowieści, często o mitycznym znaczeniu. Dwie z tych opowieści, traktujące o katastrofie fabryki, jak zasygnalizowano już wcześniej, stały się inspiracją dla Wilhelma Sasnala do stworzenia pomnika, co zresztą potwierdził sam autor.

Pierwsza z nich oparta była na cieniu obawy przed wyciekiem bliżej nieokreślonej substancji chemicznej i mówiła o tym, co robić, gdy do takiej sytuacji dojdzie: 
Wiązało się to przede wszystkim z bliskością Zakładów, stąd historia o tym, że jeżeli będzie awaria w fabryce i ulotnią się jakieś chemikalia, to trzeba zasłaniać okna mokrymi kocami (Czuję 2010, s. 206).

W tym dość syntetycznym opisie widać dwa aspekty związane z cieniem. Po pierwsze, jak tworzy się cień - obawę (cień) przed awarią i skażeniem determinowało i potęgowało sąsiedztwo Zakładów Azotowych. Po drugie, jaki jest efekt oddziaływania cienia na otoczenie społeczne - chodzi o permanentną gotowość do działania wyrażoną słowami: „trzeba zasłaniać okna mokrymi kocami” (Czuję 2010). Interesujące jest to, że zaprezentowaną przez artystę opowieść można traktować jak mit, mity są bowiem swego rodzaju drogowskazem i tłumaczą, jak zachować się w sytuacjach niepewności (Campbell 2019), w tym przypadku awarii fabryki. Warto też podkreślić, że źródłem opowiedzianej przez Sasnala historii była jego babcia - ta okoliczność jest doskonałą ilustracją wertykalnego (międzypokoleniowego) tworzenia się zbiorowego wyobrażenia, przenoszenia cienia ku przyszłości.

Subtelne przejawy tej opowieści można też odnaleźć w samym pomniku, choć należy zaznaczyć, iż przedstawiony tutaj punkt widzenia trzeba postrzegać w sposób raczej metaforyczny. Gdy dokładnie przyjrzeć się monumentowi, widać, że każdy z jego kręgów pokryty jest smołą. Odnosi się to jednak wyłącznie do określonego, dolnego i wewnętrznego fragmentu każdej rury kanalizacyjnej (widać do na zbliżeniu pomnika na fotografii 3).

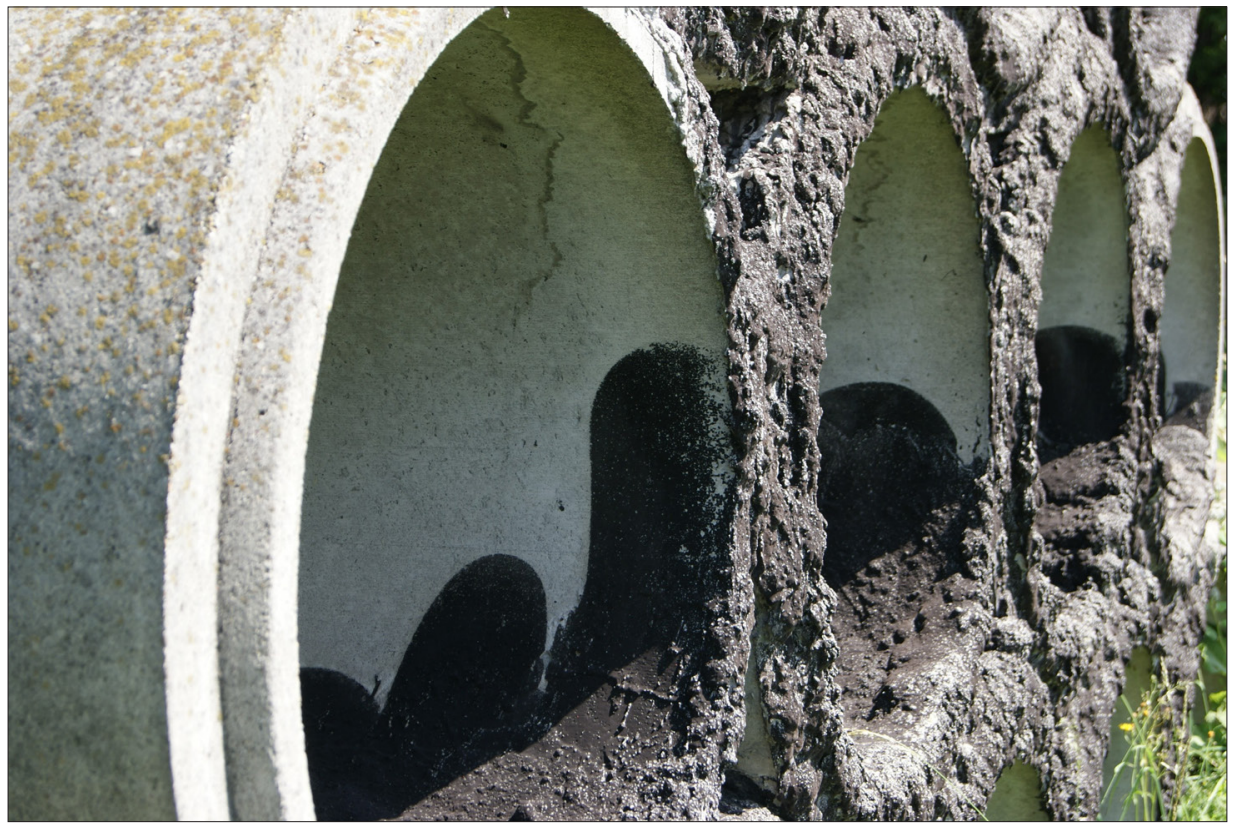

Fotografia 3. Widok na pokryte smołą kręgi pomnika Wilhelma Sasnala, lipiec $2020 \mathrm{r}$. Źródło: archiwum autora. 
Zdaniem twórcy pomnik należy traktować jako obiekt, który jest stworzony z elementów czegoś, co wcześniej istniało; jest to „taka pozostałość, taka »resztkówka «" (Sasnal 2020). Być może w wizji artystycznej Sasnala kręgi te tworzyły (zanim powstał pomnik) pewną hipotetyczną całość, były elementem czegoś większego. Co ciekawe, jeśli dokonać prostej operacji myślowej i połączyć wszystkie kręgi w jeden ciąg, to można wyobrazić sobie, że tak skonstruowanym rurociągiem, po jego dnie, w bliżej nieokreślonej przeszłości, płynęła czarna smolista ciecz, której zaschnięte „resztkówki” wyeksponowane są w elementach pomnika. W ten oto metaforyczny sposób pomnik może łączyć się z opowieścią o awarii fabryki, podczas której do kanalizacji Mościc wpłynęła jakaś toksyczna ciecz.

Drugą opowieścią przedstawioną przez Wilhelma Sasnala, która krążyła wśród mieszkańców Mościc i stała się punktem wyjścia do budowy monumentu, jest historia nuklearnego ataku ze strony Stanów Zjednoczonych na Zakłady Azotowe. Jak podkreśla twórca: „Mościce przez długie lata żyły w strachu przed katastrofą. Mówiło się, że jedna z amerykańskich rakiet jest wycelowana w zakłady" (Pawłowski 2010).

Mówiąc: „Mościce przez długie lata żyły w strachu”, Wilhelm Sasnal wypowiada się w liczbie mnogiej, w imieniu swoim i innych mieszkańców, co wskazuje, że lęk dotyczył określonej zbiorowości. Można jednak zadać pytanie, dlaczego akurat taki rodzaj katastrofy, dlaczego właśnie wizja ataku nuklearnego stała się elementem zbiorowego wyobrażenia mościczan. Warto też zapytać, jaki aspekt działalności fabryki można uznać za źródło cienia, czyli „strachu przed katastrofą” nuklearną (Pawłowski 2010). Otóż zdaniem Dawida Radziszewskiego chodziło o wytwarzane przez Zakłady Azotowe produkty, które prawdopodobnie mogły mieć znaczenie militarne i dlatego w sposób szczególny pobudzać lęk społeczny:

po wojnie zakłady się cały czas rozwijały. No i była taka plotka wśród mieszkańców, że amerykańskie rakiety są wycelowane w te zakłady, że jakby doszło do jakiegoś konfliktu nuklearnego, no to w te zakłady trafi amerykańska rakieta. To być może było prawdą, bo oni produkowali coś tam dla wojska, jakieś nitro. Była to tego rodzaju produkcja (Radziszewski 2020).

Co ciekawe, ta determinowana obawą społeczną i powstała na jej fundamencie opowieść czy „plotka”, jak ją nazwał Radziszewski (2020), również była utrwalana społecznie. W przypadku Sasnala utrwalanie to przyjmowało postać horyzontalną, ponieważ usłyszał opowieść w szkole od rówieśników, a nie od babci, jak w przypadku poprzedniej historii (Sasnal 2020). Interesujące jest, że opowieść ta, która powstała na fundamencie cienia (obawy ataku), sama, poprzez jej rozpowszechnianie, również wzmacniała ten cień (obawę). Jest to zjawisko sprzężenia zwrotnego dodatniego, zachodzące na styku tego, co zbiorowo wyobrażone (cień), z tym, co zbiorowo doświadczalne (opowieść).

Jednak najbardziej intrygującą, nie tylko zresztą z badawczego punktu widzenia, jest informacja, do której udało się dotrzeć autorowi artykułu. Otóż w 2015 roku 


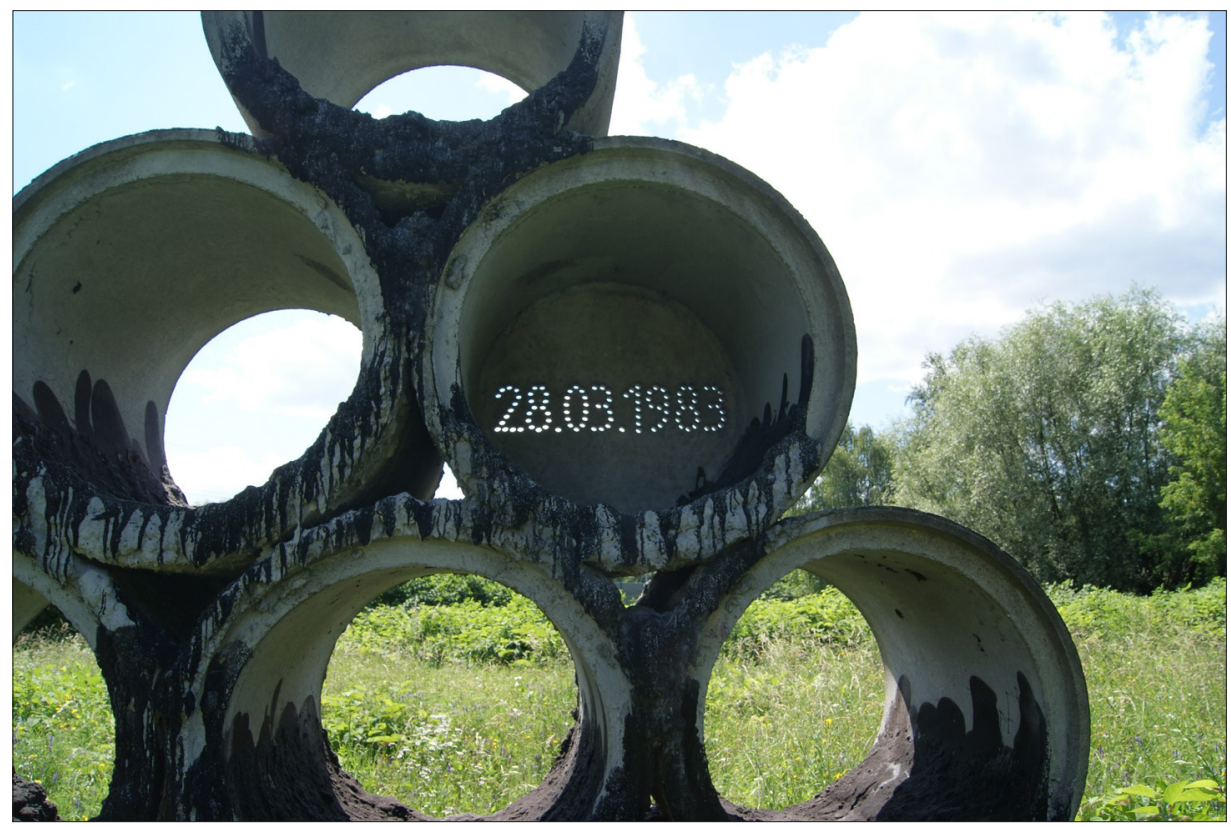

Fotografia 4. Data „28.03.1983” w jednym z kręgów pomnika Wilhelma Sasnala, lipiec 2020 r. Źródło: archiwum autora.

amerykańskie wojsko odtajniło dokumenty, wśród których znalazło się Studium Wymagań Broni Nuklearnej Strategicznego Dowództwa Lotniczego na rok 1959. W nim pojawił się zapis o miejscach, które powinny być zneutralizowane przy użyciu broni atomowej w razie wybuchu III wojny światowej. Okazało się, że jednym z celów były Zakłady Azotowe w Mościcach (20 bomb 2015). Jest to bardzo interesująca informacja w kontekście krążącej w otoczeniu społecznym fabryki opowieści o ataku, a konkretnie jej źródła. Pojawia się tutaj dylemat, nie wiadomo bowiem, czy źródłem opowieści był cień fabryki, czy może doszło do przecieku z tajnych archiwów wojsk amerykańskich i w ten sposób opowieść trafiła do szerszego obiegu. A może należy brać pod uwagę i jedno, i drugie źródło? Rozstrzygnięcie tego problemu nie wydaje się możliwe.

W każdym razie opowieść o katastrofie nuklearnej była drugą inspiracją do stworzenia pomnika. Symbolicznym nawiązaniem do tej historii jest zamieszczona w jednym betonowych kręgów monumentu data „28.03.1983” (co ilustruje fotografia 4).

Przy różnych okazjach Wilhelm Sasnal podkreślał, że data nie ma żadnego szczególnego znaczenia, że jest przypadkowa i że właśnie w tej przypadkowości można doszukiwać się sensu. Chodzi bowiem o katastrofę nuklearną, która nie miała miejsca, ale która mogła wydarzyć się kiedykolwiek. Wydaje się więc, że tego 
rodzaju data wizję katastrofy pozostawia wciąż otwartą i tym samym nie odwołuje zimnowojennego stanu zagrożenia. Przeciwnie, cień może być wciąż obecny w otoczeniu społecznym Zakładów Azotowych w Mościcach, w tym również w świadomości samego artysty.

\section{Katalizatory cienia Zakladów Azotowych}

Cień to siła, która wpływa na życie ludzi. Opowieści o katastrofie Zakładów Azotowych oraz pomnik Wilhelma Sasnala są „namacalnymi” przejawami cienia rzucanego przez fabrykę w Mościcach. Kwestie przejawów cienia, zwłaszcza jego podwójnej postaci, już poruszono, natomiast $\mathrm{w}$ tym miejscu warto podjąć dyskusję na temat tego, w jaki sposób cień powstaje, jak jest wzbudzany w otoczeniu społecznym organizacji. Powyżej wspomniano o dwóch takich katalizatorach, przy czym oba były związane $\mathrm{z}$ charakterem produkcji w fabryce, po pierwsze, $\mathrm{z}$ jej toksycznością, po drugie, $z$ wytwarzaniem produktów na potrzeby wojska. Podkreślono równiez, że pośrednim katalizatorem są również opowieści, które są wyrazem cienia, ale pozostając w obiegu społecznym, same ten cień odtwarzają. Istnieją jednak jeszcze inne elementy, które mogą inicjować powstawanie cienia, a o których warto wspomnieć. Są to rzeczywiste zdarzenia, a także zjawiska oraz miejsca i obiekty fizyczne.

$\mathrm{Na}$ tworzenie się zbiorowego niepokoju u mościczan wpływały autentyczne wypadki mające miejsce na terenie fabryki, do których, ze względu na charakter produkcji, dochodziło stosunkowo często. Informacje tego typu rozprzestrzeniały się $\mathrm{w}$ otoczeniu przedsiębiorstwa i zalegały w zbiorowej wyobraźni. Jedną z takich historii przedstawił Wilhelm Sasnal; z jej okolicznościami zaznajomiła go mama. Ona, cytując artystę:

pamięta z dzieciństwa jak była katastrofa na Zakładach Azotowych, to znaczy katastrofa... wiem, że były ofiary śmiertelne. [To było - przyp. autora] rzeczywiste zdarzenie. To musiały być pewnie lata 50., 60., to było jej dzieciństwo i to była taka historia (Sasnal 2020).

Inną historię, również o sporym ładunku emocjonalnym, która zakodowała się w pamięci, zaprezentował Dawid Radziszewski:

tam raz po raz coś wybuchało na tych zakładach, cały czas coś wybucha. Tam parę lat temu, zanim tę wystawę zrobiliśmy, to wywaliło im taki wielki zbiornik, i ten zbiornik znalazł się kilometr dalej. No bo to jest niebezpieczna produkcja, i ci mieszkańcy trochę żyli w cieniu tej fabryki, tej niebezpiecznej produkcji (Radziszewski 2020).

Radziszewski prawdopodobnie nie był świadkiem tego wydarzenia, natomiast całkiem możliwe, że dowiedział się o nim przez rozmowę z inną osobą lub przekaz 
medialny. Podkreślił natomiast wagę wpływu tego typu sytuacji na środowisko społeczne, wskazując, że „mieszkańcy trochę żyli w cieniu tej fabryki, tej niebezpiecznej produkcji” (Radziszewski 2020). Cień ten zapewne często towarzyszy mościczanom, gdyż tego typu opowieści pojawiało i pojawia się wiele. O podobnych, mniej lub bardziej drastycznych zdarzeniach, można przeczytać w mediach; choćby o wybuchu z 2019 roku, jaki miał miejsce podczas przelewania łatwopalnych substancji:

W sobotę 1 czerwca około godziny 16.45 doszło do poważnego wypadku na terenie tarnowskich Zakładów Azotowych. W wyniku wybuchu ranny został jeden pracownik. Do szpitala został przetransportowany śmigłowcem Lotniczego Pogotowia Ratunkowego (Tarnów 2019).

Innym katalizatorem cienia są różnego rodzaju zjawiska natury fizycznej, których źródłem jest fabryka w Mościcach. Mowa tu o ogniu, dymie, oparach, które pojawiają się przy okazji wielu awarii, ale też o industrialnych odgłosach, które zdaniem Sasnala wyrażają „pracę fabryki” (Sasnal 2020). Opisowo to zresztą przedstawił:

mieszkałem tak blisko, że słyszałem w nocy zakłady non-stop, ja słyszałem pracę fabryki (...). To był taki „szuuum”, szum, ale nie raz, to był taki permanentny szum, który dochodził z fabryki. A nieraz to było takie głośne, bardzo złowrogie, takie spuszczanie pary czy czegoś takiego, takie „szzzzzz...”. I jeszcze to było takie dudniące, które dochodziło... I oni robili to w nocy. No i syrena, która wyła o 7, 15 i o 23 (...). Codziennie. Zmiany, koniec zmiany. Czyli właściwie mogłeś sobie regulować zegarek. To ciekawe, że ja nie pamiętam, nie przypominam sobie dzwonów kościelnych, natomiast pamiętam syrenę (Sasnal 2020).

Słowa artysty nie tylko świadczą o tym, że zakładowe dźwięki porządkują życie mościczan („mogłeś sobie regulować zegarek”), ale są również przesłanką ku zrozumieniu wpływu fabryki na formowanie się cienia. Trzeba zauważyć, że te „dudniące”, „głośne” i „permanentne” odgłosy są według Sasnala jednocześnie „złowrogie”. Tymczasem „złowrogość” nie jest właściwością samych zjawisk dźwiękowych, jest natomiast wyobrażeniem, kategorią mentalną przypisywaną takim zjawiskom, co więcej, kategorią o negatywnym zabarwieniu, związaną z obawą. "Złowrogość”, czyli niepokój powodowany przemysłowymi odgłosami, nie wydaje się być czymś wyjątkowym, jednostkowym. Jest to raczej kategoria społeczna stanowiąca istotny element wyobrażenia zbiorowego mieszkańców Mościc. Podobne do powyższego świadectwa można bowiem odnaleźć w przekazach medialnych. W listopadzie 2016 roku mieszkańcy Mościc zwrócili uwagę na dochodzący z terenu fabryki szum. Wyjątkowa intensywność tego dźwięku i brak wiedzy na temat jego przyczyny spowodowały, że zaczęto snuć domysły co do skutków. Ilustracją tego jest wypowiedź jednego z mieszkańców: „Nikt nas nie informuje, co jest przyczyną tego hałasu, dlatego boimy się, czy do powietrza nie przedostają się jakieś niebezpieczne substancje" (Marcinek 2016). 
Nie tylko więc sam hałas, ale też brak informacji na temat jego przyczyn stają się katalizatorem cienia, na co wskazują słowa: „boimy się”. Mało tego, cień ten, jak każde wyobrażenie zbiorowe, można powiedzieć, zakrzywia rzeczywistość. Powoduje pojawienie się domysłów, $\mathrm{w}$ tym przypadku związanych $\mathrm{z}$ wyciekiem niebezpiecznych substancji; przypuszczenia te niekoniecznie mają związek z prawdą. Istnieje wiele interesujących wątków zakrzywiania rzeczywistości przez cień fabryki w Mościcach, niestety nie ma tutaj miejsca, by je odpowiednio zgłębić. Temat ten mógłby jednak stać się punktem wyjścia do kolejnych publikacji.

Trzecim wreszcie katalizatorem cienia, a właściwie kategorią katalizatorów, są związane z organizacją miejsca i obiekty fizyczne, których znaczenie w kontekście badań społecznych podkreślali Mildred Reed Hall oraz Edward Hall (1975/2001). W odniesieniu do Zakładów Azotowych należy zwrócić uwagę na dwa elementy: zadrzewione tereny oraz szczekaczki.

Szczekaczki, czyli megafony uliczne, porozstawiane są w wielu miejscach Mościc. Połączone są z siedzibą Zakładów Azotowych, skąd można nadawać ważne dla lokalnej społeczności komunikaty. Obecnie nie pełnią już swojej funkcji, jednakże, jak wskazuje Wilhelm Sasnal: „pierwotnie służyły do tego, aby w razie awarii ostrzegać mościczan" (Sasnal 2020). U mieszkańców Mościc, którzy jak Sasnal, wiedzą, jakie jest przeznaczenie tych obiektów, ich widok może przywoływać i jednocześnie utrwalać cień, wizję tego, że w każdym momencie szczekaczki mogą zostać ponownie uruchomione, by przesłać komunikat o zagrożeniu. To ten rodzaj obawy połączony z fascynacją był zapewne impulsem do wykorzystania przez Sasnala megafonów na potrzeby interwencji artystycznej, w ramach której przez tydzień, dwa razy w ciągu dnia, o godz. 11.00 i 15.00, puszczany był z głośników utwór muzyczny (Sasnal 2020).

Innym elementem, który może przywoływać widmo awarii, są, paradoksalnie, zielone, zadrzewione tereny Mościc. Chociaż Mościce były zaprojektowane zgodnie z ideą miasta-ogrodu (Bułdys 2010), to jednak, no co zwraca uwagę Dawid Radziszewski, miejsca zielone stworzono:

nie tylko dlatego, że taka była koncepcja modernistycznej czy późnomodernistycznej zabudowy i urbanistyki, tylko też dlatego, że te drzewa miały stanowić taki bufor. W razie gdyby coś tam się ulotniło, to one miały chronić mieszkańców. No i czasem coś się tam ulatnia. No może nie dotyczy to osiedla mieszkaniowego, ale czasem jakiś rolnik ma pole i czasami coś tam spadnie, jakaś chemia, i po prostu jest problem. A więc nie są takie niewinne te drzewa i bezinteresowne (Radziszewski 2020).

Podobnie więc jak w wypadku szczekaczek owe zadrzewione miejsca również mogą być katalizatorem obaw i w ten sposób kształtować wyobraźnię. Jednak z drugiej strony są naturalnym buforem, nie tylko w sensie fizycznym, który zabezpiecza przez rozprzestrzenieniem się toksycznych substancji, ale też w znaczeniu metafizycznym, przyroda bowiem przesłania cień, pozwala oswoić się ze 
zbiorowym wyobrażeniem lęku. Również z tego punktu widzenia obecność terenów zielonych w miejscach zurbanizowanych i zindustrializowanych stanowi wartość samą w sobie.

\section{Podsumowanie}

W tekście naszkicowano obraz najważniejszych aspektów cienia, czyli odczucia lęku towarzyszącego mieszkańcom Mościc. Dominującym aspektem tego lęku jest wizja katastrofy fabryki, przyjmująca dwa oblicza (awarii zakładów i ataku nuklearnego). Wizja ta wyrażana jest w opowieściach, które, niczym podróżujące idee (Czarniawska 2010), przemieszczają się w obrębie otoczenia społecznego organizacji w sposób wertykalny (w czasie) i horyzontalny (w ramach grupy), co zapewnia im ciągłość trwania i odpowiedni zasięg. Opowieści są jednym z „widocznych” przejawów cienia i organizują życie społeczne, stając się choćby inspiracją dla artystów. W taki sposób powstał pomnik Wilhelma Sasnala „28.03.1983”. W opracowaniu zwrócono również uwagę na to, co inicjuje cień w otoczeniu społecznym organizacji. Wyróżniono kilka takich katalizatorów: rzeczywiste zdarzenia, zjawiska natury fizycznej oraz miejsca i obiekty. Warto jednak zaznaczyć, że artykuł odnosi się tylko do pewnej części problematyki cienia Zakładów Azotowych, skoncentrowano się bowiem na cieniu, który przejawiał się w twórczości Sasnala, a przede wszystkim w pomniku jego autorstwa. Pozakatastroficznych postaci stanów lękowych w otoczeniu mościckiej fabryki może być jednak więcej. Ich identyfikacja byłaby możliwa za sprawą wdrożenia odpowiednich badań społecznych, choćby przeprowadzenia grupowych lub pogłębionych wywiadów indywidualnych z mieszkańcami dzielnicy Tarnowa. Badania mogłyby się stać punktem wyjścia do kolejnych prac o cieniu.

Oczywiście kwestia tak rozumianego cienia nie jest przypisana wyłącznie Zakładom Azotowym. Przykład ten jest tylko swego rodzaju ilustracją zjawiska, o którym tu mowa, dotyczy ono natomiast także innych organizacji. Badania nad cieniem warto jednak prowadzić tam, gdzie można się go spodziewać, gdzie można przyjąć, że działalność organizacji może w sposób szczególny oddziaływać na otoczenie społeczne, przyczyniając się do formowania zbiorowych wyobrażeń lęku. Można brać pod uwagę zatem nie tylko organizacje przemysłu ciężkiego, ale także banki, kluby nocne, zakłady karne, a nawet szpitale. Przykładów można podać wiele, choć wybór zależy przede wszystkim od interesującego badacza rodzaju cienia. $\mathrm{Na}$ przykład w przypadku laboratoriów mikrobiologicznych może to być strach przed wydostaniem się i rozprzestrzenieniem drobnoustrojów. Co ciekawe, eksplorację cienia jako figury niepokoju społecznego można też prowadzić wewnątrz organizacji, np. w obrębie władzy, dyskryminacji, mobbingu i wielu innych problemów. We wszystkich tych przypadkach można wykorzystać durkheimowską kategorię wyobrażeń zbiorowych. 
Na koniec warto zastanowić się, jakie wnioski można wyciągnąć z niniejszej pracy, jaki rodzaj wiedzy jest w niej zawarty i co z niej wynika. Po pierwsze, wyjaśniono i pokazano na przykładach, czym jest cień istniejący w otoczeniu organizacji. Jest to rodzaj lęku społecznego, strachu przed różnego rodzaju zagrożeniami (awariami, katastrofami) ze strony organizacji, na które narażone są osoby mieszkające w jej otoczeniu. Po drugie, ukazano, że cień jest osadzony w przeszłości, ponieważ ludzie sięgają do swojej pamięci i przypominają sobie niebezpieczne sytuacje, których byli świadkami lub o których słyszeli. Po trzecie, cień jest projektowany na przyszłość. Oznacza to, że ludzie doświadczeni przeszłymi wydarzeniami spodziewają się, że prędzej czy później pojawi się kolejne zagrożenie. Po czwarte, pokazano, jak wygląda mechanizm powstawania i rozpowszechniania się cienia w otoczeniu organizacji. Jego źródłem jest sama organizacja, natomiast rozwija się on poprzez opowieści o zagrożeniach, które ludzie wzajemnie sobie przekazują. I wreszcie po piąte, wyjaśniono, w jaki sposób cień organizuje życie ludzi, a efektem tego są określone postawy społeczne, ale też opowieści, w tym mity, i działania artystyczne (czego dobrym przykładem jest twórczość Wilhelma Sasnala).

\section{Bibliografia}

\section{Opracowania}

20 bomb (2015), 20 bomb na Poznań, 15 na Warszawę, dziesiątki na inne miasta. Plany USA na III wojné światowa, TVN24 bis, 25.122015, https://tvn24.pl/swiat/plany-bombardowanatomowych-w-polsce-odtajniony-dokument-sac-ra605767-3321566 [odczyt: 16.09.2020]. Arcydzieło (2008), Arcydzieło w cieniu zakładów azotowych, Dziennik.pl, http://www.dziennik.pl/podroze/article206944/Arcydzielo_w_cieniu_zakladow_azotowych.html [odczyt: 15.09.2020].

Bowles M.L. (1991), The Organizational Shadow, „Organization Studies”, Vol. 12, No. 3, s. 387-404. Biały K. (2015), Opowieści biograficzne, [w:] M. Kostera (red.), Metody badawcze w zarzadzaniu humanistycznym, Warszawa: Sedno, s. 71-80.

Bułdys B. (2010), Mościce - sen o nowoczesności, [w:] E. Łączyńska-Widz, D. Radziszewski (red.), Tarnów. 1000 lat nowoczesności. Przewodnik, Warszawa-Tarnów: Stowarzyszenie 40000 Malarzy, Biuro Wystaw Artystycznych Galeria Miejska w Tarnowie, s. 129-175.

Burduş E. (2011), Shadow Management, „Review of International Comparative Management”, Special Number 1, s. 135-140.

Burrell G., Morgan G. (1979), Sociological Paradigms and Organisational Analysis, Portsmouth, NH: Heinemann.

Campbell J. (2019), Potęga mitu, tłum. I. Kania, Kraków: Wydawnictwo Znak. 
Carr A. (2002), Jung, Archetypes and Mirroring in Organizational Change Management: Lessons from a Longitudinal Case Study, „Journal of Organizational Change Management”, Vol. 15 , Iss. 5, s. 477-489.

Czarniawska B. (2002), Interviews and Organizational Narratives/f, [w:] J.F. Gubrium, J. Holstei (eds.), Handbook of Interviewing, Thousand Oaks: Sage, s. 733-750.

Czarniawska B. (2010), Trochę inna teoria organizacji. Organizowanie jako konstrukcja sieci działań, Warszawa: Wydawnictwo Poltext.

Czuję (2010), Czuję, że tam wcią̇̇ można wiele. Rozmowa z Wilhelmem Sasnalem, [w:] E. Łączyńska-Widz, D. Radziszewski (red.), Tarnów. 1000 lat nowoczesności. Przewodnik, WarszawaTarnów: Stowarzyszenie 40000 Malarzy, Biuro Wystaw Artystycznych Galeria Miejska w Tarnowie, s. 193-210.

Drabik L., Kubiak-Sokół A., Sobol E., Wiśniakowska L. (oprac.) (2007), Słownik języka polskiego $P W N$, Warszawa: Wydawnictwo Naukowe PWN.

Durkheim É. (1901/2000), Zasady metody socjologicznej (przedmowa do wydania drugiego), tłum. J. Szacki, Warszawa: Wydawnictwo Naukowe PWN.

Durkheim É. (1912/2010), Elementarne formy życia religijnego. System totemiczny w Australii, tłum. i wstęp A. Zadrożyńska, Warszawa: Wydawnictwo Naukowe PWN.

Garfinkel H. (2007), Studia z etnometodologii, tłum. A. Szulżycka, Warszawa: Wydawnictwo Naukowe PWN.

Geertz C. (2005), Interpretacja kultur. Wybrane eseje, tłum. M.M. Piechaczek, Kraków: Wydawnictwo Uniwersytetu Jagiellońskiego.

Gierszewska G., Romanowska M. (2003), Analiza strategiczna przedsiębiorstwa, Warszawa: Polskie Wydawnictwo Ekonomiczne.

Hall M.R., Hall E.T. (1975/2001), Czwarty wymiar w architekturze. Studium o wptywie budynku na zachowanie człowieka, tłum. R. Nowakowski, Warszawa: Warszawskie Wydawnictwo Literackie MUZA.

Hatch M.J. (2002), Teoria organizacji, tłum. P. Łuków, Warszawa: Wydawnictwo Naukowe PWN. Kopaliński W. (2001), Słownik symboli, Warszawa: Oficyna Wydawnicza Rytm.

Kostera M. (2003), Antropologia organizacji. Metodologia badań terenowych, Warszawa: Wydawnictwo Naukowe PWN.

Kostera M. (2010), Organizacje i archetypy, Warszawa: Wolters Kluwer.

Kostera M., Śliwa M. (2012), Zarządzanie w XXI wieku, Warszawa: Wolters Kluwer.

Laberschek M. (2019a), Znaczenie pomników przedsiębiorstw w przestrzeni społecznej, „Przegląd Socjologii Jakościowej”, t. 15, nr 3, s. 136-161.

Laberschek M. (2019b), Monumentalne wizerunki. Pomniki jako obrazy przedsiębiorstw, „Zarządzanie w Kulturze”, t. 20, nr 2, s. 199-220.

Laberschek M. (2021), Monuments to Enterprises in Communist-era Poland. The Creation and Consolidation of an Organizational Identity through Art, [w:] M. Kostera, C. Woźniak (eds.), Aesthetics, Organization, and Humanistic Management, New York, London: Routledge, Taylor \& Francis Group, s. 150-171. 
Latour B. (1986), The Powers of Association, [w:] J. Law (ed.), Power, Action and Belief - A New Sociology of Knowledge?, London-Boston-Henley: Routledge \& Kegan Paul, s. 261-277. Łączyńska-Widz E., Radziszewski D. (red.) (2010), Tarnów. 1000 lat nowoczesności. Przewodnik, Warszawa-Tarnów: Stowarzyszenie 40000 Malarzy, Biuro Wystaw Artystycznych Galeria Miejska w Tarnowie.

Maison D. (2010), Jakościowe metody badań marketingowych. Jak zrozumieć konsumenta, Warszawa: Wydawnictwo Naukowe PWN.

Marcinek P. (2016), Dziwne dźwięki z Azotów zagrażają mieszkańcom?, plus.gazetakrakowska.pl, https://plus.gazetakrakowska.pl/dziwne-dzwieki-z-azotow-zagrazaja-mieszkancom/ ar/11487468 [odczyt: 16.09.2020].

Mytych J. (2018), Pionki na biało-czerwonej szachownicy: polityczny i medialny dyskurs o pomnikach na przykładzie „Czterech śpiących”, „Organów” Hasiora oraz rzeszowskiego Pomnika Walk Rewolucyjnych, „Naukowy Przegląd Dziennikarski”, nr 2, s. 65-94.

Pawłowski R. (2010), Chemia Sasnala, wyborcza.pl, Duży Format, 5.12.2010, https://wyborcza. pl/duzyformat/1,127290,8762034,Chemia_Sasnala.html [odczyt: 15.09.2020].

Policht P. (2020), Artystyczny przewodnik po Tarnowie, Culture.pl, https://culture.pl/pl/artykul/ artystyczny-przewodnik-po-tarnowie [odczyt: 15.09.2020].

Rosenow E. (1899/2010), Die im Schatten Leben, Berlin: Contumax Gmbh \& Co. Kg.

Silverman D. (2012), Interpretacja danych jakościowych. Metody analizy rozmowy, tekstu i interakcji, tłum. M. Głowacka-Grajper, J. Ostrowska; wprow. K.T. Konecki, Warszawa: Wydawnictwo Naukowe PWN.

Sörensen J., Olsson E.J. (2020), Shadow Management: Neoliberalism and the Erosion of Democratic Legitimacy through Ombudsmen with Case Studies from Swedish Higher Education, „Societies”, 10(2), 30, s. 1-13.

Sułkowski Ł. (2007), Recepcja nurtu interpretatywnego w naukach o zarządzaniu, [w:] K. Konecki, P. Chomczyński (red.), Zarzadzanie organizacjami: organizacja jako proces, Łódź: Wydawnictwo Uniwersytetu Łódzkiego, s. 22-30.

Tarnów (2019), Tarnów. Wybuch w Zakładach Azotowych. Ranny pracownik, tarnow.naszemiaasto.pl, https://tarnow.naszemiasto.pl/tarnow-wybuch-w-zakladach-azotowych-rannypracownik/ar/c14-514947 [odczyt: 16.09.2020].

Weick K. (2016), Tworzenie sensu w organizacjach, tłum. B. Czarniawska, Kraków: Wydawnictwo Uniwersytetu Jagiellońskiego.

\section{Materialy badawcze}

Sasnal W. (2020), Transkrypcja wywiadu autora $z$ Wilhelmem Sasnalem.

Radziszewski D. (2020), Transkrypcja wywiadu autora z Dawidem Radziszewskim. 